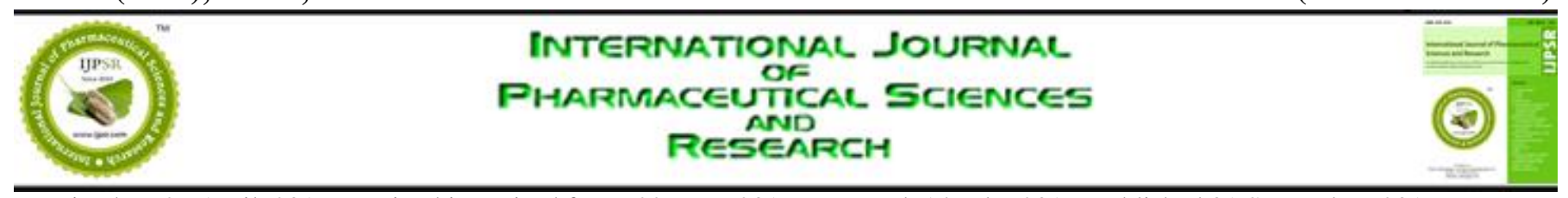

Received on 26 April, 2016; received in revised form, 22 May, 2016; accepted, 14 July, 2016; published 01 September, 2016

\title{
DEVELOPMENT OF HERBAL MOSQUITO REPELLENT FORMULATIONS
}

\author{
M. S. N. Ranasinghe ${ }^{* 1}$, L. Arambewela ${ }^{1}$ and S. Samarasinghe ${ }^{2}$
}

College of Chemical Sciences ${ }^{1}$, Institute of Chemistry Ceylon, Adamantane House, No.341/22, Kotte Road, Welikada Rajagiriya, Sri Lanka.

Sri Lanka Medical Research Institute ${ }^{2}$, Colombo - 08, Sri Lanka.

\section{Keywords:}

Formulations, Mosquito Repellent Activity, Plant Extract, Essential Oil

\section{Correspondence to Author:}

Miss. M. S. N. Ranasinghe

(Grad. Chem, A. I. Chem. C.)

Teaching Assistant, College of Chemical Sciences, Institute of Chemistry Ceylon, Adamantane House, No.341/22, Kotte Road, Welikada, Rajagiriya, Sri Lanka

E-mail: nipunisashi@yahoo.com

\begin{abstract}
The present study reports the studies directed towards the development of safe and efficient herbal mosquito repellent formulations obtained by mixing hexane extract of Azadirachta indica seeds, hexane/ethanol extract of Vitex negundo leaves, essential oils from Ocimum sanctum leaves, Curcuma longa rhizomes and Citrus sinensis peels and essential oils of Cymbopogon nardus leaves, Eucalyptus globules leaves and Syzygium aromaticum buds purchased from the market. $1 \mathrm{ml}$ of $10 \%(\mathrm{v} / \mathrm{v} \%)$ extract / essential oil containing ethanol solutions prepared using each plant extract / essential oil was tested for mosquito repellent activity using arm-incage method. A volunteer's forearm rubbed with $1 \mathrm{ml}$ test solution was exposed to 20 blood-seeking mosquitoes and the number of mosquitoes that aligned or biting the arm was recorded in each minute for five minutes. Analysis was carried out as a triplicate and mosquito repellent activities were found to be in the order: Cymbopogon nardus and Eucalyptus globulus (100\%) >Ocimum sanctum (97.94\%) $>$ Syzygium aromaticum $(95.81 \%)>$ Citrus sinensis $(93.75 \%)>$ Curcuma longa $(89.56 \%)>$ Vitex negundo $(85.44 \%)>$ Azadirachta indica $(81.25 \%)$. Outdoor and indoor field trials on mosquito repellent gel and mosquito repellent spray prepared containing $16 \%(\mathrm{v} / \mathrm{v} \%)$ active ingredients were conducted separately on two days from 5 am to 11 am by application on volunteers' legs. $100 \%$ mosquito repellency up to six hours was observed for the gel and the spray for outdoor and indoor field trials.
\end{abstract}

INTRODUCTION: Mosquitoes are among the most disturbing blood sucking insects afflicting human beings 1,2 . Several mosquito species belonging to genera Anopheles, Culex and Aedes are vectors for the pathogens of various diseases like Dengue fever, Malaria, Yellow fever, Japanese Encephalitis and several other infections ${ }^{3}$. Mosquitoes alone transmit diseases to more than 700 million people and over one million deaths are reported annually across the globe ${ }^{4,5}$. Therefore, the control of mosquitoes is an important public health concern around the world.

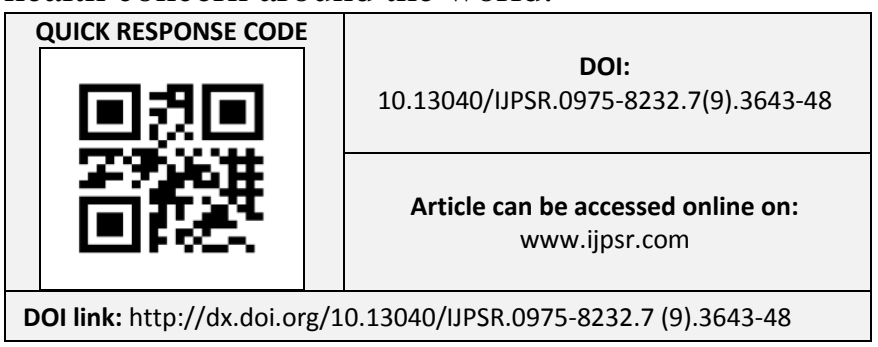

As most of the mosquito repellent products and devices available in the market are reported to have harmful effects on human beings, the objective of the present study is to develop effective plant-based mosquito repellent products.

\section{MATERIALS AND METHODS:}

The selection of the plants was based on their availability as raw materials, scientific evidence and folkloric use as mosquito repellents.

\section{Preparations of the Plant Extracts:}

Crushed Azadirachta indica (Neem) seeds ${ }^{2}, 966.67$ $\mathrm{g}$, were soaked in hexane solvent, $1,960 \mathrm{ml}$, overnight at room temperature with occasional shaking. The hexane extract was filtered and the filtrate was concentrated by rotary evaporator at around $45^{\circ} \mathrm{C}$. Same procedure was carried out for the second extraction using squeezed Neem seeds. 
Finally, the total extract, was weighed and stored in refrigerator at $4^{\circ} \mathrm{C}$ until it was used for the experiment.

Vitex negundo (Nika) leaves ${ }^{6}, 835.72 \mathrm{~g}$, were cut into small pieces and were soaked in hexane solvent, 3, $500 \mathrm{ml}$, overnight at room temperature with occasional shaking. Then, the hexane extract was filtered and the filtrate was concentrated by rotary evaporator under $45^{\circ} \mathrm{C}$. Same procedure was repeated using squeezed Nika leaves and hexane solvent. Finally, the total extract was weighed and stored in refrigerator at $4^{\circ} \mathrm{C}$ until it was used for the experiment. The leaves that were extracted with hexane were soaked in ethanol solvent, $3,000 \mathrm{ml}$, for one day at room temperature with occasional shaking. Then the ethanol extract was filtered and the filtrate was concentrated using the rotary evaporator $\left(55-60^{\circ} \mathrm{C}\right)$. Same procedure was carried out for the second extraction using squeezed Nika leaves. Finally, the total extract was weighed and stored in refrigerator at $4^{\circ} \mathrm{C}$ until it was used for the experiment. For the experiment, hexane extract of Nika and ethanol extract of Nika were mixed together in 1:1 ratio.

\section{Preparations of the Essential Oils:}

Hydro-distillation process was separately performed for Ocimum sanctum (Tulsi) leaves ${ }^{7}$, 718.90 g; Curcuma longa (Turmeric) rhizomes ${ }^{8,9}$, 700.00 g; Citrus sinensis (Sweet Orange) peels ${ }^{3}$, 1,144.52 g using Clevenger-arm apparatus. Water was added to the weighed quantity of plant material in a round bottom flask which was placed on a heating mantle and the flask was connected with the Clevenger-arm apparatus. Flow of water was allowed to run in the condenser. While boiling, the volatile oils were carried along with the steam into the graduated distillate receiving tube and excess water returned to the flask. A layer of solvent, mixture of dichloromethane and diethyl ether (1:1 ratio), was added to the distillation arm. The essential oils dissolved in the organic solvent mixture which was in the graduated distillate receiving arm. Heating was continued for about 5 hours and assembly was allowed to cool. At last, aqueous layer and organic layer were collected separately. Then the organic layer was allowed to dry over anhydrous sodium sulphate and aqueous layer was extracted twice with dichloromethane.
Finally, the combined solvents were evaporated and essential oil was obtained. Essential oil was weighed and stored in refrigerator at $4^{\circ} \mathrm{C}$ until it was used for the experiment.

Essential oils of Cymbopogon nardus (Citronella) leaves ${ }^{8,9}$, Eucalyptus globulus (S. Eucalyptus) leaves ${ }^{10}$ and Syzygium aromaticum (Clove) buds ${ }^{2}$ were purchased from Citro Essential Oils (PVT) Ltd, Sri Lanka.

\section{Preparation of the Test Solutions:}

$10 \%$ (v/v\%) plant extract or essential oil containing ethanol solutions were prepared using each plant extract and essential oil. $0.3 \mathrm{ml}$ of each plant extract or essential oil was mixed with 3 drops of Tween 80. Then ethanol was added until the volume was $3 \mathrm{ml}$.

In order to prepare the control test solution, ethanol was added to 3 drops of Tween 80, until the volume was $3 \mathrm{ml}$.

\section{Testing the Mosquito Repellent Activity of Plant Extracts/Essential Oils Using Arm-In-Cage Method:}

The mosquitoes used in this experiment were caught using a net while biting humans between 7 $\mathrm{pm}$ and $10 \mathrm{pm}$. Mosquitoes were starved for 24 hours and 20 mosquitoes were placed in the cage $(45 \times 15 \times 30 \mathrm{~cm})$. Test timing was between $7 \mathrm{pm}$ and $10 \mathrm{pm}$ since the mosquitoes typically bite at night. Host-seeking behaviour of the mosquitoes was tested prior to the experiment. This was done by placing a pre-cleaned hand in the cage and counting the number of mosquitoes that aligned within 10 seconds. If at least 5 mosquitoes aligned on the hand, the mosquitoes inside the cage were regarded as host-seeking and the repellency experiment was continued.

Volunteer's forearm which had been rubbed with 1 $\mathrm{ml}$ of the test solution was exposed to the cage and the number of mosquitoes that aligned or biting the arm was recorded in each minute for 5 minutes. Mosquitoes were given an over one hour interval and the above procedure was followed for each of the other plant extracts and essential oils. Each test was repeated thrice to get a mean value of mosquito repellent activity. 
Preparation of the Mosquito Repellent Gel and the Mosquito Repellent Spray:

After analysing the mosquito repellent activity of individual plant extracts and essential oils, a mosquito repellent gel and a mosquito repellent spray which contained $16 \% \quad(\mathrm{v} / \mathrm{v} \%)$ active ingredients each were prepared as shown in Table 1.

TABLE 1: THE CONSTITUENTS IN THE MOSQUITO REPELLENT GEL AND THE MOSQUITO REPELLENT SPRAY

\begin{tabular}{ccc}
\hline Constituents & Quantity in Gel & Quantity in Spray \\
\hline Citronella essential oil & $10.00 \mathrm{ml}$ & $10.00 \mathrm{ml}$ \\
Eucalyptus essential oil & $10.00 \mathrm{ml} \mathrm{ml}$ \\
Tulsi essential oil & $3.00 \mathrm{ml}$ & $3.00 \mathrm{ml}$ \\
Clove bud essential oil & $7.00 \mathrm{ml} \mathrm{ml}$ \\
Sweet Orange peel essential oil & $6.00 \mathrm{ml}$ & $7.00 \mathrm{ml}$ \\
Turmeric essential oil & $4.00 \mathrm{ml}$ & $6.00 \mathrm{ml}$ \\
Nika extract & $12.00 \mathrm{ml}$ & $4.00 \mathrm{ml}$ \\
Neem extract & $12.00 \mathrm{ml} \mathrm{ml}$ \\
Hexane & $6.00 \mathrm{ml} \mathrm{ml}$ \\
Ethanol & $5.00 \mathrm{ml}$ & $12.00 \mathrm{ml}$ \\
Carbapol & $5.00 \mathrm{~g}$ & $6.0000 .00 \mathrm{ml}$ \\
Propylene glycol & $20.00 \mathrm{ml}$ & - \\
Methyl paraban & $0.50 \mathrm{~g}$ & - \\
Tween 80 & $6.00 \mathrm{ml}$ & - \\
Triethanol amine & Few drops & $30.00 \mathrm{ml}$ \\
Distilled water & $293.50 \mathrm{ml}$ & - \\
\end{tabular}

Bio-Efficacy Testing of the Mosquito Repellent Gel and the Mosquito Repellent Spray:

Bio-efficacy tests of the mosquito repellent gel and the mosquito repellent spray were done in collaboration with Medical Research Institute, Sri Lanka. Outdoor and indoor field trials were conducted in two days from 5 am to 11 am by separately applying the mosquito repellent gel and the mosquito repellent spray on volunteers' legs. Untreated legs of another volunteer were used as control for this experiment.

\section{RESULTS AND DISCUSSION:}

The yields of the extracts and the essential oils were determined as a percentage $(\mathrm{w} / \mathrm{w} \%)$ using the formula,

Percentage yield of plant extract or essential oil $=$

$$
\frac{\text { Weight of plant extract or essential oil }}{\text { Initial weight of the plant material }} \times 100
$$

Table 2 shows the percentage yields (w/w\%) of the extracts and the essential oils which were obtained in the laboratory,

TABLE 2: PERCENTAGE YIELDS OF THE EXTRACTS AND THE ESSENTIAL OILS

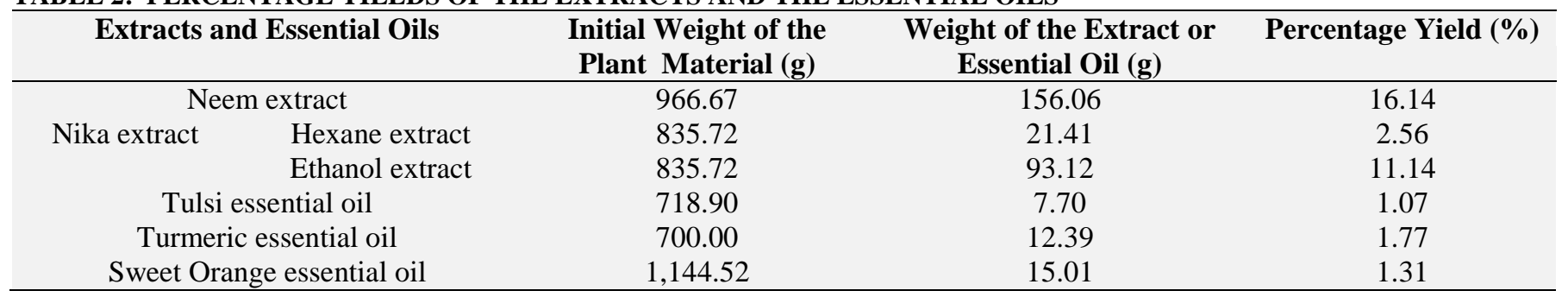

Percentage the mosquito repellency for plant extract/essential oil shown in Table $\mathbf{3}$ was calculated as below,

Percentage mosquito repellency $=\frac{\mathrm{C}-\mathrm{N}}{\mathrm{C}} \times 100$

Where, $\mathrm{C}=$ Number of mosquitoes aligned/left and aligned/bit when the solvent was used;
$\mathrm{N}=$ Number of mosquitoes aligned/left and aligned/bit when the extract or the essential oil was used

Table 3 indicates the mean values of the mosquitoes aligned/left and aligned/bit for plant extracts/ essential oils and repellency (percentages) of plant extracts/essential oils. 
TABLE 3: MEAN VALUES OF THE MOSQUITOES ALIGNED/LEFT AND ALIGNED/BIT FOR PLANT EXTRACTS/ ESSENTIAL OILS AND MOSQUITO REPELLENCY (PERCENTAGES) OF PLANT EXTRACTS/ESSENTIAL OILS

\begin{tabular}{|c|c|c|c|c|c|}
\hline $\begin{array}{l}\text { Plant Extracts/ } \\
\text { Essential Oils }\end{array}$ & $\begin{array}{c}\text { Replicate } 1 \\
\text { Total Number of } \\
\text { Mosquitoes } \\
\text { Aligned/Left and } \\
\text { Aligned/Bit }\end{array}$ & $\begin{array}{c}\text { Replicate } 2 \\
\text { Total Number of } \\
\text { Mosquitoes } \\
\text { Aligned/Left and } \\
\text { Aligned/Bit }\end{array}$ & $\begin{array}{c}\text { Replicate } 3 \\
\text { Total Number of } \\
\text { Mosquitoes } \\
\text { Aligned/Left and } \\
\text { Aligned/Bit }\end{array}$ & $\begin{array}{c}\text { Calculated Mean } \\
\text { Value of } \\
\text { Mosquitoes } \\
\text { Aligned/Left and } \\
\text { Aligned/Bit } \\
\end{array}$ & $\begin{array}{c}\text { Percentage } \\
\text { Mosquito } \\
\text { Repellency }(\%)\end{array}$ \\
\hline $\begin{array}{l}\text { Neem extract } \\
10 \%(\mathrm{v} / \mathrm{v} \%)\end{array}$ & 4 & 2 & 3 & 3.00 & 81.25 \\
\hline $\begin{array}{l}\text { Tulsi essential oil } \\
10 \%(\mathrm{v} / \mathrm{v} \%)\end{array}$ & 0 & 1 & 0 & 0.33 & 97.94 \\
\hline $\begin{array}{c}\text { Turmeric essential oil } \\
10 \%(\mathrm{v} / \mathrm{v} \%)\end{array}$ & 2 & 3 & 0 & 1.67 & 89.56 \\
\hline $\begin{array}{c}\text { Sweet Orange essential } \\
\text { oil } 10 \%(\mathrm{v} / \mathrm{v} \%)\end{array}$ & 1 & 2 & 0 & 1.00 & 93.75 \\
\hline $\begin{array}{l}\text { Eucalyptus essential oil } \\
10 \%(\mathrm{v} / \mathrm{v} \%)\end{array}$ & 0 & 0 & 0 & 0.00 & 100.00 \\
\hline $\begin{array}{l}\text { Clove bud essential oil } \\
10 \%(\mathrm{v} / \mathrm{v} \%)\end{array}$ & 1 & 0 & 1 & 0.67 & 95.81 \\
\hline $\begin{array}{c}\text { Solvent (Ethanol and } \\
\text { Tween 80) }\end{array}$ & 18 & 14 & 16 & 16.00 & 0.00 \\
\hline
\end{tabular}

Table 4 indicates the number of mosquitoes which areas of legs within 6 hours. Untreated legs of aligned/left and aligned/bit the volunteers' treated another volunteer were used as a control.

TABLE 4: BIO-EFFICACY TEST RESULTS OF THE MOSQUITO REPELLENT GEL

\begin{tabular}{|c|c|c|c|c|c|c|c|c|}
\hline \multirow{2}{*}{ Time } & \multicolumn{4}{|c|}{ Day 1} & \multicolumn{4}{|c|}{ Day 2} \\
\hline & \multicolumn{2}{|c|}{ Indoor } & \multicolumn{2}{|c|}{ Outdoor } & \multicolumn{2}{|c|}{ Indoor } & \multicolumn{2}{|c|}{ Outdoor } \\
\hline $5-6 a m$ & 04 & 0 & 05 & 0 & 02 & 0 & 04 & 0 \\
\hline $7-8$ am & 18 & 0 & 15 & 0 & 14 & 0 & 16 & 0 \\
\hline $8-9$ am & 13 & 0 & 14 & 0 & 15 & 0 & 17 & 0 \\
\hline $9-10 a m$ & 07 & 0 & 08 & 0 & 09 & 0 & 11 & 0 \\
\hline
\end{tabular}

Table 5 indicates the number of mosquitoes which aligned/left and aligned/bit the volunteers' treated areas of legs within 6 hours. Untreated legs of another volunteer were used as a control.

TABLE 5: BIO-EFFICACY TEST RESULTS OF THE MOSQUITO REPELLENT SPRAY

\begin{tabular}{|c|c|c|c|c|c|c|c|c|}
\hline \multirow[b]{3}{*}{ Time } & \multicolumn{4}{|c|}{ Day 1} & \multicolumn{4}{|c|}{ Day 2} \\
\hline & \multicolumn{2}{|c|}{ Indoor } & \multicolumn{2}{|c|}{ Outdoor } & \multicolumn{2}{|c|}{ Indoor } & \multicolumn{2}{|c|}{ Outdoor } \\
\hline & Control & Spray & Control & Spray & Control & Spray & Control & Spray \\
\hline $5-6$ am & 05 & 0 & 03 & 0 & 03 & 0 & 05 & 0 \\
\hline $6-7$ am & 12 & 0 & 10 & 0 & 10 & 0 & 09 & 0 \\
\hline $7-8$ am & 17 & 0 & 13 & 0 & 16 & 0 & 18 & 0 \\
\hline $8-9$ am & 15 & 0 & 16 & 0 & 15 & 0 & 16 & 0 \\
\hline $9-10 a m$ & 08 & 0 & 09 & 0 & 12 & 0 & 10 & 0 \\
\hline $10-11 \mathrm{am}$ & 06 & 0 & 05 & 0 & 07 & 0 & 06 & 0 \\
\hline
\end{tabular}

According to the indoor and outdoor field trials which were carried out for a six-hour time period each day for two days, both the mosquito repellent gel and the mosquito repellent spray have shown $100 \%$ mosquito repellency. The findings of this study could be varied to many factors such as the 
species of mosquito, quality of the plant extracts and the essential oils and the characteristics of volunteers, namely, age, sex and bio-chemical attractiveness to mosquitoes. The quality of the extracts and the essential oils depends on many factors such as plant species, growth conditions, maturity of plants, plant storage, plant preparation and methods of extraction.

Many researchers have shown that plant essential oils have better repellent efficacy rather than plant extracts. However, all the essential oils are highly volatile and this contributes to their poor longevity as mosquito repellents. Therefore, many essential oils are not suitable to be used as sole mosquito repellents. This problem is addressed in the current study by preparing two herbal mosquito repellent formulations using highly volatile essential oils together with herbal extracts.

No skin irritations or rashes were observed on the arms of the test volunteers with extracts, essential oils and the two mosquito repellent formulations. However, a hot sensation was observed on the arms of the test volunteers with Clove bud essential oil. Therefore, the slight hot sensation which was observed on the arms of the test volunteers with two mosquito repellent formulations may also be due to Clove bud essential oil. Further improvements for the two mosquito repellent formulations can be done by reducing the Clove bud essential oil to the level where no hot sensation is observed. Also, formulations containing lower percentages of active ingredients have to be prepared and evaluated for their efficacy. Further investigations are needed to elucidate the efficacy of the two herbal mosquito repellent formulations against a wide range of mosquito species and also to identify active compounds responsible for mosquito repellent activity in order to utilise them if necessary, in preparing a commercial product to be used as a mosquito repellent.

CONCLUSION: Plant essential oils showed higher mosquito repellent activities compared to plant extracts. The mosquito repellent gel and the mosquito repellent spray which contained $16 \%$ $(\mathrm{v} / \mathrm{v} \%)$ total active ingredients each, showed $100 \%$ mosquito repellency for outdoor and indoor field trials which were carried out for six hours each day for two days.

ACKNOWLEDGEMENT: Financial Assistance provided by College of Chemical Sciences, Institute of Chemistry Ceylon, Rajagiriya, Sri Lanka and the Bio-efficacy testing services provided by Medical Research Institute, Colombo 08, Sri Lanka are greatly appreciated.

\section{REFERENCES:}

1. Imeda C, Katani S, Kitu A, Kitufe N, Magesa S, Magogo F, Malebo H, Malecela M, Malima R, Massaga J, Matata D, Mbogo G, Mhame P, Mwaiko G, Nyigo V, Ogondiek J, Sunguruma R, Tungu P, Wiketye V: Repellence effectiveness of essential oils from some Tanzanian Ocimumand Hyptisplant species againstafro-tropical vectors of malaria and lymphaticfilariasis. Journal of Medicinal Plants Research 2013; 7: 653-660

2. Makhaik M, Naik SN, Tewary DK: Evaluation of antimosquito properties of essential oils. Journal of Scientific and Industrial Research 2005; 64:129-133

3. Adeogun AO, Adewuyi GO, Etatuvie SO, Fawehinmi AB, Lawal HO: Bioassay of Herbal Mosquito Repellent Formulated from the Essential Oil of Plants. Journal of Natural Products 2012; 5: 109-115

4. Mohomed AA, Tarek IAAM, Zarrag IAA: Larvicidal and repellent effect of some Tribulus terrestris L., (Zygophyllaceae) extracts against the dengue fevermosquito, Aedesaegypti (Diptera: Culicidae). Journal of Saudi Chemical Society 2012: 1-7

5. WHO 2014. A Global Brief on Vector-Borne Diseases. http://apps.who.int/iris/bitstream/10665/111008/1/WHO_ DCO_WHD_2014.1_eng.pdf (Cited on 04 ${ }^{\text {th }}$ June, 2015)

6. Pradhan SS, PatelRK: Preparation of Low Cost Herbal Mosquito Repellent from Begunia Leaf [online], Department of Chemistry, Rourkela National Institute of Technology: Rourkela:1-25. http://ethesis.nitrkl.ac.in/ 2105/1/sushree_thesis.pdf (Cited on 1st October, 2014)

7. Mahour K, Prakash S, Singh S: Evaluation of Mosquito Repellent Efficacy of Ocimum Sanctum Plant Extract. Journal of Herbal Medicine and Toxicology 2009; 3: 87-90

8. Poungjai S, Soonwera M, Sritabutra D, Waltanachanobon S: Repellent activity of herbal essential oils against Aedesaegypti (Linn.) and Culexquinquefasciatus (Say.). Asian Pacific Journal of Tropical Disease 2011: 124-128

9. Pandey D, Rani N, Vidyarthi A, Wany A: Study of Citronella leaf based herbal mosquito repellents using natural binders [online]: 98-103.http://crmb.aizeon publishers. net/content/2013/3/crmb98-103.pdf (Cited on $1^{\text {st }}$ October, 2014)

10. Ghalandari R, Heidari S, Kashani HH, Shooshtari MB: Comparative mosquito repellent efficacy of alcoholic extracts and essential oils of different plants against Anopheles Stephensi. African Journal of Pharmacy and Pharmacology 2013; $7:$ 310-314 
How to cite this article:

Ranasinghe MSN, Arambewela L and Samarasinghe S: Development of Herbal Mosquito Repellent Formulations. Int J Pharm Sci Res 2016; 7(9): 3643-48.doi: 10.13040/IJPSR.0975-8232.7(9).3643-48.

All @ 2013 are reserved by International Journal of Pharmaceutical Sciences and Research. This Journal licensed under a Creative Commons Attribution-NonCommercial-ShareAlike 3.0 Unported License.

This article can be downloaded to ANDROID OS based mobile. Scan QR Code using Code/Bar Scanner from your mobile. (Scanners are available on Google Playstore) 